\title{
Authentic Leadership and Its Role in Building Psychological Contracts
}

\author{
Rakesh Rayiramkandath \\ Research Fellow in Organizational Leadership, National School of Leadership, NSL House, Culture Crest, \\ Spine Rd, Moshi Pradhikaran, Sector No. 6, Moshi, Pune - 412105, Maharashtra, India; \\ rrkdath@gmail.com
}

\begin{abstract}
The concept of psychological contract has been gaining importance in the recent times along with the theory of authentic leadership. It is the prerogative of the leaders to understand the psychological contract between themselves and their employees as it provides them with a competitive advantage in creating a motivational work environment where equity is valued. Four companies, namely, Costco, PwC, Southwest Airlines and Aravind Eye Hospital were selected for case study analysis in this study with respect to impact of authentic leadership on the building of psychological contracts. It was found that the leadership style does have a significant positive impact on building of psychological contracts between the employer and employee in an organization.
\end{abstract}

Keywords: Aravind Eye Hospital, Authentic Leadership, Costco, Organizational Leadership, Psychological Contract, PwC, Southwest Airlines, TATA Group, Work Environment

\section{Introduction}

Authentic leadership approach is not different from other leadership styles including transactional, transformational, and charismatic or servant. It is different from the actual meaning of the concept of authenticity which can be regarded as a vital quality of a leader which is usually acquired through increasing self-awareness and acceptance, trust, beliefs, morals, actions and by fostering relationships. (Goldman, 2012, p.134) has observed that "psychological authenticity can be theorized as a vibrant set of processes by which one's full innate nature is discovered, accepted, instilled with meaning, and actualized". Authentic leadership is increasingly gaining importance regarding increasing worldwide concerns as well as the resultant demands for authenticity (Gardner, Avolio, Luthans, May, \& Walumbwa, 2015; Klenke, 2016).

Concerning this, Walumbwa et al. (2008) added this and theorized self-awareness, relational transparency, balanced processing, and internalized moral perspective as the four main pillars of authentic leadership. Selfawareness is the leader's awareness about own strengths, weaknesses, and values while relational transparency is showing leader's true self, balanced processing is weighing all available information including those from followers before making a decision, and internalized moral perspective is having high moral values (Kernis, 2003; Ilies, Morgeson, \& Nahrgang, 2005; Avolio \& Gardner, 2005; Walumbwa et al., 2008; Neider \& Schriesheim, 2011). Bass (1985) and Richter \& Wagner (2014) studied new generation leadership models and concluded that authentic leadership is important because it focuses on reducing barriers between a leader and followers along with building cooperation and delegation. Authentic leadership is getting more important in today's competitive and digitalized world as digitalization is bringing a new set of challenges. Due to digitalization, organizations are forced to adapt to the evolving commercial landscape by 
moving on to data driven decision making, establishing new methods of communication, and working with a workforce who has omnipresent access to information (Zhao, Zuo, \& Deng, 2015; Haas, Criscuolo, \& George, 2015; Hesse, 2018). Avolio et al. (2004) explained that authentic leaders attempt to find a solution for any kind of challenge in a credible way through communication, cooperation, transparency, genuineness, and high moral values.

On the other hand, a psychological contract is a verbal contract as opposed to a formal, codified contract which defines the expectations between the employer as well as the employee. It basically consists of casual provisions, shared attitude, familiar ground and perceptions between both the sides (Sherman \& Morley, 2015). A psychological contract is said to be very important since it is not formal and codified and perpetually exists in a condition of instability and is constantly developing with the increase in communication. The main advantage of a psychological contract as compared to a formal contract is that it is focused more on the individual and thus, each contract can be different owing to the different nature of each employee (Bellou, 2009). This study aims to determine the impact of authentic leadership on psychological contracts by observing selected recent cases.

The findings of this study is unique and significant because there is a lack of evidence observing recent cases which exemplify how responsibilities and roles of an authentic leader can contribute to psychological contract. It also delves into the importance of building psychological contracts within the present business environment and discusses the elements which can impact the contract.

The present business environment is constantly evolving owing to a number of uncontrollable external and internal changes. This not only creates dynamic changes in the people relations within the organisations, but warrants proactive evolution of strategies to manage the relations too. The lack of recent evidence observing practical case examples on the impact of authentic leadership on psychological contract creates a bridge in existing research, limiting the potential for identifying such strategies too. Therefore, this study will bridge this gap by shedding light on how psychological contract in the organization influences the behaviour and motivation of an employee from day to day. It is essential as it maintains a balanced and robust relationship between the employer and employee, which is required for efficient business performance and increased productivity.

\section{Literature review}

\section{a. Importance and Constituents of Authentic Leadership}

Authentic leadership has been defined as "a process by which a leader influences people to accomplish certain objectives or a common goal" (Sharma \& Jain, 2013). Noting the same, Rousseau, Hansen \& Tomprou (2018) argued that authentic leaders are those individuals who are concerned as well as aware of their skills, strengths, and limitations. Further, it is worth noting that the role of these leaders is gaining considerable significance in the current intense business environment. The reason behind this is that authentic leaders focus on the significant picture results, and they practice self-awareness.

A leader is required to widen his or her leadership skills by application of knowledge, experiences, and training. He is also required to possess various personality traits including vision of the future, strong resolve, high energy and confidence, as well as sound judgment (Jago, 1982). These constituents are vital for authentic leadership as it is widely known that personality, traits along with behavior of leaders have a significant impact in value creation, enhancement of people's strength, strategizing and implementing knowledge. Authenticity essentially means being true to oneself along with their surroundings (Terry, 1993, p. 139) and is a desirable quality of a leader since it helps in influencing others."

Though the concept of authenticity in leadership has fully emerged in recent years, it now essentially means a focus of responsible behavior of leaders. The theory of authentic leadership, thus, emphasizes on authenticity as an essential trait of a leader that helps a leader to be authentic through self-knowledge, faith, actions and relationships, promotion of authentic relationships with their followers and associates, supported by transparency, trust, integrity and high moral standards (Besen, Tecchio, \& Fialho, 2015). Thus, an authentic leader is consistent in his behavior and his inner thoughts and feelings (Novicevic, Harvey, Buckley, Brown, \& Evans, 2006). On the other side, Sendjaya et al., (2016) claims that the 
authentic leader needs to maintain confidentiality in some cases too. The business scenario has to maintain with proper system and procedures. Thus, while maintaining secrecy, the hierarchy and procedures should be followed.

\section{b. Meaning and Features of Psychological Contracts}

Psychological contracts support the idea that individuals reciprocate their experiences and therefore, it is important to lead them accordingly. Also, the treatment of employees by an organization has an impact on their attitude as well as behavior. The main features of psychological contracts include:

- Communication - It has been seen that managers who support psychological contracts actively work to improve communication with their employees. The communication includes continuing oral and printed communication and two-way support between management as well as the employees. In contrast, Rego, Júnior \& e Cunha (2015) found that a psychological contract also involves understanding the managers' unsaid expectations and concerns of the team members. This demonstrates the capability of emotional intelligence of authentic leaders. Such leaders effectively apply the emphatic skills in the workplace. Diversity - Individual psychological contracts allow the employees to see their value and role within the business. It also helps both sides avoid creating unrealistic expectations of one another by allowing for amendments in the terms of the contract when required in order to maintain the diversity.

- Leveraging the employee-manager relationship - The relationship between the employer and employee can be leveraged by equipping and encouraging managers to converse and concentrate on psychological contract outlook with employees. Managers help the employees in exploring and modifying their expectations by offsetting negative actions in case of not meeting idealistic expectations.

- Reciprocity - Levinson et al. (2013) studied psychological contracts in light of mutual expectations between an employee and an employer that arose from unconscious motives.
The authors explained this mutual expectation comes automatically when an employer hires a new employee. The employer expects employees to meet the organization's expectations if the needs of the employees are fulfilled by the organization. The authors argued this anticipation of meeting each other's needs and expectations motivates both parties in favor of a long-term bond and continued relationship. Taylor \& Tekleab (2004) argued the range of expectation is from highly specific to general so the psychological contract changes when both parties have a more detailed understanding of the contribution of the other party and due to change in circumstances.

- Flexibility - Argyris (1960) considered a psychological contract as an implicit understanding between employers and employees where employees exchange higher productivity and lower grievances for wages and job security. The study prescribed practitioners to focus on promoting flexibility than explicit norms. Taylor \& Tekleab (2004) explained employees would promote and respect the rights of the organization if the organization does not interfere much in employee norms and this will be reflected in productivity.

- Personality - Nikolaou, Tomprou, \& Vakola (2007) studied psychological contracts with respect to the employment agreement and considered personality traits as one of the most important psychological contracts. The researchers argued extrovert individuals are more social, adventurous, frank, talkative, and assertive while introverts are reserved, shy, quiet, and less social so extroverts are intrinsically motivated and easily influenced and encouraged at work, as a result, they get an upper hand in an organization. Consequently, introverted individuals need to get motivated by the leaders. Thereby, authentic leaders can play a significant role in helping introverts by giving them some space and respecting their privacy.

The expansion of authentic leadership draws upon and generates optimistic psychological capacities and a constructive corporate culture (Walumbwa, Avolio, Gardner, Wernsing, \& Peterson, 2008). It also serves as a dependable and successful leadership model which 
helps in building credibility in the unsteady context of the organization. A study by (Yarbrough, 2009)found that an authentic leadership was positively related to relational psychological contract and negatively related to transactional psychological contract.

\section{c. Role of Authentic Leadership on Psychological Contracts}

Avolio \& Gardner (2005) studied the role of authentic leadership on psychological contracts and illustrated that authentic leadership backed by positive moral perspective and positive psychological capital makes the leader of an organization self-aware, as a result, the leader becomes self-regulated, and it is reflected in the leadership behavior of the leader. The role of a leader in an organization from an organization's productivity perspective is to motivate and encourage followers. Apart from this, a leader is also responsible for evaluating the performances of the subordinates and identifying the gaps in their work performances to enhance the level of productivity. Besides, motivation and encouragement to attain better work results, guidance and coaching are also the roles of a leader.

When the leader of an organization has authentic leadership qualities such as effective communication, high morality, unbiasedness, transparency, etc. followers are automatically motivated, and they try to adapt these qualities as a result followers become self-aware and selfregulated. The organization becomes a beneficiary of this transparent, interactive, regulated, and aware workforce because such a workforce would not only know about their strengths but also drawbacks (Avolio \& Gardner, 2005).

\section{a. Role of authentic leadership in building 'COMMUNICATION' psychological contract}

Guest \& Conway (2002) identified three types of communication in an organization: communication during recruitment, day to day work related communication, and top down communication. The researchers found an inverse relation between psychological contract breach and recruitment communication and day to day communication. However, the study found top down approach is ineffective. Robinson \& Morrison (2000) believed communicating the psychological contract with the human resource manager is very important because it clarifies expectations related to workload, work culture, appraisal, job security, etc. The authors pointed out lack of communication can lead to misunderstanding and psychological contract breaches so in order to reduce the occurrence of such cases, both the parties should take the initiative of starting a communication.

Smidts, Pruyn \& Van Riel (2001) identified communication climate as one of the biggest assets of an organization. The researchers defined communication climate as the way in which information flows and processes in an organization. The authors argued if leaders of an organization engage in extensive top down communication and use multiple channels of communication to ensure a fast flow of information then an organization can increase its identification in terms of organizational commitment of employees and cooperation. From the perspective of an organization, the effectiveness of a communication will depend on what kind of psychological contract model is being used by the senior management and whether it is appropriate or needs a change. Regarding communication, Boekhorst (2015) debates that if communication is effective and strong within the workplace, it will lead to lower psychological contract breach among the workforce. On the contrary, if the communication or interaction is mediated by lower power distance then it will result in lower psychological contract breach.

\section{b. Role of authentic leadership in building 'DIVERSITY' psychological contract (200 words)}

Rousseau (1995) defined a psychological contract with respect to social exchange theory and considered it as a set of beliefs between an employee and an organization. Due to the changing work environment, nature of psychological contracts has evolved and now organizations have unique psychological contract such as diversity for a specific group of employees (Arlie, 2001; Guest \& Conway, 2009). The diversity contract represents nondiscrimination for racial, cultural, and ethnic differences (Rousseau, 2004; Cunningham, Barbee, \& Mandal, 2009). Chrobot-Mason (2003) explained diversity related psychological contracts like considering minority input in the process of decision making, eliminating racial bias, eliminating ethnic bias, etc. Are increasingly being used by organizations 
to nurture and encourage diversity. Wellin (2016) has explained that it is becoming essential to nurture inclusivity and diversity in the workplace.

Buttner, Lowe, \& Billings-Harris (2010) explained that despite its increasing importance, breaches in diversity related psychological contract occurs when minority employees find their organization is unable to fulfill its diversity related promises. Disrespect, disregard, devaluation, and ignorance of minority identity damage the employment relationship of minority employees so organizations should acknowledge diverse identities to achieve workplace harmony and achieve reap the benefits of acculturation (Tufan, De Witte, \& Wendt, 2019).

\section{c. Role of authentic leadership in building 'LEVERAGING THE EMPLOYEE- MANAGER RELATIONSHIP’ psychological contract}

Caldwell \& Peters (2018) and Conway \& Briner (2005) explained that a newly recruited employee builds psychological contract expectations after interacting with leaders and colleagues and engaging in tasks. The authors prescribed organizations to have a robust onboarding system because it is the precursor of developing a dyadic psychological contract between leaders and workers. Rousseau \& Tijoriwala, (1996) and Horney (2016) suggested organizations to establish a clear dyadic psychological contract relationship so that workers are aware of what to expect from the organization and what the organization is expecting in return. Relating to this phenomenon, Rousseau, Hansen \& Tomprou (2018) emphasized that setting clear expectations and clarity in roles are important aspects for strengthening employment relations.

Lemmon et al. (2016) and Gupta et al. (2018) believed communication and organizational socialization can leverage the relationship between leaders and workers so the authors explained that senior management should always try to communicate with the new recruits and existing pool of employees with symmetric weightage. Rousseau and Tijoriwala (1996, 1998) emphasized on equitable working conditions, fair dealing, and a transparent and fair reward system to leverage the relationship between employees and managers.

\section{d. Role of authentic leadership in building 'RECIPROCITY' psychological contract}

Göbel, Vogel, \& Weber (2013) ascribed cooperation, labour relation, and consumer relation under the domain of the utilitarian approach. Smith (1937) theorized that in an exchange, both parties can benefit in terms of welfare if both parties are driven by a utilitarian mindset. However, the author also emphasized morality and considered without it, market exchange would be impossible. Güth (1995), Hirshleifer (1988), Kreps et al. (1982), Williamson (1993), and Coleman (1990) propagated that every cooperative relationship can be reduced to a calculation of benefit so organizational interactions are solely driven by utilitarian motives. Rousseau $(1995,2001)$ argued that although a psychological contract is based on the perception of reciprocity, some degree of objective mutuality is essential because the employer and the employee aim at achieving an interdependent goal. The authors argued communication between the two parties helps both parties to align their future behaviors with their actual commitments. Engle \& Lord (1997) emphasized on frequent communication and information sharing between the two parties for appropriate reciprocity. The argument concerning this has been presented by Wellin (2016) mentioning that authentic leaders should establish a continuous and open communication platform. This the crucial role of the leaders and top executives of the organization to maintain a culture where everyone has provided an equal opportunity to reveal their opinions.

Coyle-Shapiro \& Kessler (2000) and Porter et al. (1998) argued that often leaders and employees have different understandings regarding specific terms of an exchange so the two parties should be transparent about their demands and the extent of compromises.

\section{e. Role of authentic leadership in building 'FLEXIBILITY' psychological contract}

McLean Parks et al. (1998) conceptualized employees consider dimensions like stability, scope, tangibility, focus, time frame, particularism, multiple agencies, and volition as flexibility so organizations that tend to offer these perks attract more long-term employees. Guest (2004) identified factors like workload, employment security, job satisfaction, and well-being as the important constituents 
of analyzing flexibility. Marler et al. (1998) studied contact workers and commented them as boundary less workers due to their flexibility. Tremlett and Collins (1999) found almost $25 \%$ of UK workers prefer such employment opportunities to full time employment because employees are increasingly wishing not to lose individual freedom by getting into a commitment. Studies conducted by other researchers have found a percentage between 25 to 44 with added reasoning like family circumstances, age, and educational qualification (Barringer \& Sturman, 1999; Krausz et al.,1995; Ellingson et al., 1998; Marler et al., 1998). These studies show how leaders emphasizing flexibility by offering contract employment derive twodimensional benefit of higher productivity and less liability. The studies noted that as a drawback such leaders tend to create less loyal and valuable employees in the long run so the researchers prescribed leaders to grant efficient contract workers full time employment perks to influence them for a full time contract.

\section{f. Role of authentic leadership in building 'PERSONALITY' psychological contract}

Costa \& McCrae (2008), Raja et al. (2004); and Tallman \& Bruning (2008) defined personality as a stable pattern of behaving across different situations. Goldberg (1990) constructed a five-factor model to understand the influence of personality traits on psychological contract breaches. The five factors are extraversion (excitability, sociability, talkativeness, and assertiveness), emotional stability (potential to withstand stress), conscientiousness (reliability), agreeableness (cooperativeness), and openness (creativity and curiosity). DelCampo (2007) found agreeableness, openness, and conscientiousness, reduced the likelihood of psychological contract breach while the other two factors extraversion and emotional stability increased the likelihood of violation. However, it is been critically analyzed by Sendjaya et al., (2016) that personality is linked with the employer obligation and employee obligation.

\section{Research gap}

In light of the literature reviewed above, it can be seen that even though there is a limited amount of literature connecting leadership to different psychological contracts, concrete evidence connecting different types of leadership to them is lacking. Existing literature fails to shed light through examples how different leadership styles create benefits and challenges for a firm as far as psychological contracts pertaining to employees is concerned. Moreover, there is no speculation or evidence regarding how it affects the firm's productivity, output and longevity. Therefore, this is a critical gap in literature.

\section{Research Methodology}

For the purpose of this research, secondary research available in various sources such as books, reports, research papers, and official websites of companies was referred to. The reports were qualitative as well as quantitative in nature. The findings of the studies were presented in the form of case studies, i.e., case study analysis has been performed. Cases referring to the relationship between psychological contracts and leaderships styles have been presented descriptively.

\subsection{Case Studies}

Case 1 - Costco

Costco is a multinational large-scale retail chain that boasts of motivated employees working due to its belief that it is important to invest considerably on manpower development. The employment policies of Costco are efficient and conducive for employees which is set on the belief that employees' productivity is maximum when they are satisfied with the benefits offered to them. The organization seeks to connect the employees with their vision and mission. It was observed that if employees remain in touch with organizational objectives then they work hard to achieve them by increasing the employees' commitment since they are motivated to work more and achieve more. Costco provided the employees with extra benefits and monetary incentives in order to keep the morale of the employees up ( $\&$ Gardner, 2015).

Jim Sinegal is an authentic leader of Costco who always supports authenticity in the organization. Authentic leaders are regarded as those leaders who establish an interpersonal relationship with organizational members and focus on transparency. Jim Sinegal created a huge impact on the image of the company in the market by putting the welfare of employees at the forefront, giving 
the company a competitive edge. Mr. Sinegal is an authentic leader who provided a solution to this problem by never putting any employee below him and treating them all with same respect. He believed that each member of the company had an equal and relevant value in the organization. In this way, the employees of the Costco remain motivated and satisfied with the leadership style followed by him. He also made an effort to maintain good relations with the employees by helping, guiding, teaching, coaching, and motivating them up to a great extent. Thus, it can be seen that by understanding the need $s$ and wants of employees along with providing then with guidance helped the organization in establishing strong and honest psychological contracts between the managers and employees in the organization (Courtemanche \& Carden, 2011)."

\section{Case 2 - PwC Germany}

$\mathrm{PwC}$ seeks to increase diversity and inclusiveness in the organization. The organization helps in developing their employees into authentic and inclusive leaders who inspire others. The main problem which PwC, Germany is facing includes promoting gender and generational diversity. The company has worked hard to develop authentic and successful leaders. One of the many efforts included their Up! Talk female mentoring programme which seeks to help their female millennial employees in refining and developing leadership skills which would reflect their true selves along with enable them to resonate with their colleagues. This helps the organization in creating a leadership framework that concentrated on the development of inclusive behavior as well as mindsets $(\mathrm{PwC}, 2016)$. The language of the organizational framework and its supporting career progression framework has been devised with this crucial for inclusiveness. Thus, by launching their various programs for their female leaders helped the company in providing their high-potential women with advice on advancing their careers, with allocating an experienced mentor to each of the female participants from a different PwC Line of Service (LoS) for a period of one year. These initiatives helped the leaders in sharing professional experiences, advice and feedback. These programmes helped the company in fostering an all-encompassing culture which embraces and values difference along with fostering a psychological contract of value in its environment.

\section{Case 3 - Southwest Airlines}

Southwest Airlines is a unique organization that has consistently recognized the needs of their employees. The organization has been profitable for over three decades, has the fewest customer complaints of any major airline, has an employee turnover rate that is under $10 \%$ and is constantly named an employer of choice (D'Aurizio, 2008). Southwest Airlines is an organization that maintains mission, values and goals that seeks first to support, care for and sustain their employees. The organization emphasizes communication, work life balance, ongoing learning and reciprocity between employer and employee and ultimately supports maintenance of efficient internal psychological contracts. Herb Kelleher, the former CEO of Southwest Airlines, is a perfect example of an authentic leader. (Grubbs-West, 2015)a former Director of Employment at Southwest Airlines has shared nine organizational loyalty lessons Southwest has applied to build the corporate culture of respect and reciprocity. The lessons include hire attitude, immersing everyone in the culture immediately, continue learning, people give as good as they get, bringing out the kid in everyone, do more with less, love them in tough times, doing what is correct and nurturing the corporate family." Forthe company, a good corporate citizen includes giving back to the society by way of volunteerism by making individual as well as personal or corporationwide efforts. The organization has decided to go with authentic leadership in order to improve their organizational effectiveness. Authentic leadership is, "leaders who know who they are, know what they believe in and value, and act on those values and beliefs openly and candidly. Their followers would consider them to be moral people" (Yuki, 2010). Following authentic style of leadership requires gaining trust of employees. It has been observed that following of this leadership style by Kelleher helps in improving the communication between his employees and the entire organization. The organization eventually has to invest less time in communicating, to other leaders in gaining trust of the employees and thereby maintaining efficient internal psychological contracts. 


\section{Case 4- Aravind Eye Care}

India is home to around a third of the world's total blind population with around 200 million Indians requiring eye-care. In most of the cases, blindness can be seen to be caused by factors which can be corrected. Aravind Eye Care sets a good example for authentic leadership by Dr. G. Venkataswamy who is popularly known as 'Dr. V', the founder and former chairman of Aravind Eye Hospitals. Through his difficult task and resolve, Dr. V demonstrated how to hold a scalpel and perform cataract surgery. As a result of his efforts, he had performed more than one hundred surgeries daily and successfully completed one hundred thousand victorious eye surgeries in his life span. While being in the government service, Dr. V conducted several programs to solve the difficulty of blindness in India. A number of outreach programs in eye care, a rehabilitation center for the blind, and establishment of an ophthalmic assistants' program. It is important to recognize his work in the struggle against blindness, Dr. V was recognized with the Padmashree award in 1973 by government for India.

Dr. V had a revelation to reinstate the gift of sight to a lot of poor blind people through the establishment of the Aravind Eye Care which runs on the business model based on his vision to solve the problem of blindness irrespective of the ability of the patients to pay the hefty bills. With his magnetic authentic leadership style he has been able to profitably execute this business model and has successfully emerged as the largest provider of eye care services globally. Dr.V has been able to address the problem of curable blindness and thereby created an institution with a wide range and is able to perform 400,000 eye surgeries annually.

\section{Case 5 - Tata Group}

Tata Group is an Indian multinational conglomerate based in Mumbai, Maharashtra. The business group was founded by Jamshetji Tata in 1868 . The former chairman of the group, Ratan Tata is an authentic leader who helped the group to achieve many heights post liberalization of the Indian economy in 1991. Three iconic leaders of the group from different time frames: Jamsetji Tata, JRD Tata, and Ratan Tata emphasized on human values as their core leadership philosophy. The core values of the Tata
Group are, integrity, pioneering, unity, responsibility and excellence. Jamsetji Tata belonged to the Parsi community and as an industrialist in the colonial era possessed a nationalist desire to contribute to the growth of the country. Jamshetji emphasized giving something back to the society by engaging in organized philanthropy and investing in scientific development (Tripathi \& Kumar, 2020).

Ratan Tata launched Tata Business Excellence Model in 1993 to institutionalize the pursuit of core Tata values. Ethical code of conduct, Employee focus, Founder's core values, alignment with Indian culture, and mentorship were the key constituents of the model. Unlike other business groups that are constantly in search of highly experienced professionals, Tata group tends to recruit fresh graduates and postgraduates from top education institutes and grooms them for leadership so that they carry the leadership values of Tata group (Shah, 2010). Pandey (1989) and Sinha et al. (2006) elaborated the employee friendly practices and policies undertaken by the Tata group and concluded such practices as the strength of the organization. Starting from eight hours of work per day to leave and maternal leave, the Tata group were the pioneers of the employee welfare measures. Shah (2010) highlighted one of the particular schemes of one of the most important subsidiaries of the Tata group, Tata Motors. Under the scheme, the organization pays the last drawn salary of an employee to the employee's family till his notional day of retirement if the employee dies while in service. Other credible employee welfare focused measures taken by the companies of the Tata group are the promotion of second career women through the Tata Second Careers and a return to career program for women who had to take a break due to certain circumstances through Tata Second Career Inspiring Possibilities (SCIP) platform (Shah, 2010). Shah $(2010,2014)$ concluded that with the credible authentic leadership of leaders like Ratan Tata, the Tata group has been an example of responsible capitalism even before corporate social responsibility became popular.

Ratan Tata was the chairman of Tata Group from 1990 to 2012 and again from October 2016 to February 2017. The contribution of Ratan Tata towards the growth of the nation through a wonderful combination of philanthropy and business has been recognized by the 
Indian government. The Indian government has awarded Ratan Tata with two of its highest civilian awards: Padma Vibhushan in 2008 and Padma Bhushan in 2000 .

\section{Discussion}

With the knowledge literature review and the caste studies, this paper identifies humanitarian values and credibility as the two most important characteristics of a good authentic leader that helps workers of an organization in building psychological contracts. In the literature review, many studies reflected a good percentage of new age employees are in search of contractual jobs just to cartel commitment and enjoy freedom. This researcher argues that if leaders of an organization are credible in terms of transparency and have moral values then they won't pressurize full time employees to go for an unrealistic target for the sake of achieving a nominal reward or for saving the job. In such a scenario, full time employees will have a job satisfaction with a good workload balance and contractual workers would be happy to get a full time contract with added perks.

\section{Conclusion}

The business environment is continuously evolving and so is the competition which has increased the requirement of authentic leaders. Organizational leaders must admire and respond positively in order to support positive employee perceptions. Psychological contracts are important maintain in a company in order to align the company's goals with that of the employees. These non-written contracts between the employee and their manger have a significant impact on the organizational productivity and employee retention. It is important to maintain positive psychological contracts by investing time, effort as well as resources as they have potential to increase organizational effectiveness including mutual respect, compassion, hope, understanding, equality and impartiality. It can be said that an effective reciprocity between the employer and the employees helps in restoring balance in the organization. Authentic leaders lead with empathy for their people, with the correct vision, insight, and influence, thereby fostering better psychological contracts between the firms and their employees.

\section{Recommendations}

With respect to the findings of this paper, this researcher recommends leaders of an organization to be credible, transparent, and focus on empathy to drive the productivity of the workers. The leaders should try to grab every opportunity to communicate with the workers. Topdown communication goes against equality, therefore, to promote a sense of equality, this researcher suggests implementing effective laissez faire communication as and when required. Lastly, with the focus on freedom, this researcher recommends new age leaders to be as much flexible as possible without compromising the company's goals and in case there is a risk of hurting the company's goals, the leader should try to find a solution by communicating and being transparent about the company's goals.

\section{Limitations of the Study and Scope for Further Research}

This researcher has found a lack of empirical evidence in the existing literature. Every individual researcher has used a unique and one of its kind data set so there is variance in comparative studies. This researcher also observed that due to the rapidly changing business environment and a drive towards digitalization traditional theories are becoming less efficient. Since management research is also evolving, most of the discrete qualities that are used to identify an authentic leader are also found in other forms of leadership. In the meantime, the dimension of qualities of an authentic leader has also expanded. Therefore, a new and unique definition of qualities of a new age leadership system needs to be identified.

\section{References}

Arlie, I. (2001). Flexibility versus fairness? Organizational dynamics, 29(4), 260-273. https://doi.org/10.1016/S00902616(01)00032-8

Argyris, C. (1960). Understanding Organizational Behavior. Homewood, IL: Dorsey Press. Arnold, J.

Avolio, B. J., \& Gardner, W. L. (2005). Authentic leadership development: Getting to the root of positive forms of leadership. The leadership quarterly, 16(3), 315-338. https:// doi.org/10.1016/j.leaqua.2005.03.001 
Avolio, B. J., Gardner, W. L., Walumbwa, F. O., Luthans, F., \& May, D. R. (2004). Unlocking the mask: A look at the process by which authentic leaders impact follower attitudes and behaviors. The leadership quarterly, 15(6), 801-823. https://doi.org/10.1016/j.leaqua.2004.09.003

Bellou, V. (2009). Profiling the desirable psychological contract for different groups of employees: Evidence from Greece. Int. J. Hum. Resour. Manag. 20, 810-830. https://doi. org/10.1080/09585190902770711

Besen, F., Tecchio, E., \& Fialho, F. A. P. (2015). Authentic leadership and knowledge management. Gestao and Producao, 24(1).

Barringer, M., \& Sturman, M. (1999). Contingent workers and the multiple foci of organizational commitment: A social exchange perspective. In Academy of Management, Chicago.

Bass, B. M. (1985). Leadership and Organization and performance beyond expectations.

Bellou, V. (2009). Profiling the desirable psychological contract for different groups of employees: Evidence from Greece. The Int. J. Hum. Resour. Manag. 20(4), 810-830. https:// doi.org/10.1080/09585190902770711

Besen, F., Tecchio, E., \& Fialho, F. A. P. (2017). Authentic leadership and knowledge management. Gestão \& Produção, 24, 2-14. https://doi.org/10.1590/0104-530x898-13

Buttner, E. H., Lowe, K. B., \& Billings-Harris, L. (2010). The impact of diversity promise fulfillment on professionals of color outcomes in the USA. J. Bus. Ethics, 91(4), 501-518. https://doi.org/10.1007/s10551-009-0096-y

Boekhorst, J. A. (2015). The role of authentic leadership in fostering workplace inclusion: A social information processing perspective. Human Resource Management, 54(2), 241-264. https://doi.org/10.1002/hrm.21669

Caldwell, C., \& Peters, R. (2018). New employee onboardingpsychological contracts and ethical perspectives. J. Manag. Dev. https://doi.org/10.1108/JMD-10-2016-0202

Chro-bot - Mason DL (2003), Keeping the promise : Psychological Contract Violations for minority employees, Journal of Management Psychology, Vol18,No 1, pp 22-45

Coleman, J. (1990). Foundations of Social Theory. Harvard University Press: Cambridge, Mass.

Conway, N., \& Briner, R. B. (2005). Understanding psychological contracts at work: A critical evaluation of theory and research. Oxford University Press. https://doi.org/10.1093/ acprof:oso/9780199280643.001.0001
Costa Jr, P. T., \& McCrae, R. R. (2008). The Revised Neo Personality Inventory (neo-pi-r). Sage Publications, Inc.

Courtemanche, C., \& Carden, A. (2014). Competing with Costco and Sam's Club: Warehouse club entry and grocery prices. J. Manag. Psychol., 80(3), 565-585. https://doi. org/10.4284/0038-4038-2012.135

Coyle-Shapiro, J., \& Kessler, I. (2000). Consequences of the psychological contract for the employment relationship: A large scale survey. J. Manag. Stud. 37(7), 903-930. https:// doi.org/10.1111/1467-6486.00210

Cunningham, M. R., Barbee, A. P., \& Mandal, E. (2009). Hurt feelings and the work place. Feeling hurt in close relationships, 417-456. https://doi.org/10.1017/CBO9780511770548.021

Courtemanche, C. J., \& Carden, A. (2011). Competing with Costco and Sam's Club: Warehouse Club Entry and Grocery Prices. South. Econ. J., 80(3). https://doi.org/10.3386/ w17220

DelCampo, R. G. (2007). Understanding the psychological contract: A direction for the future. Management Research News. https://doi.org/10.1108/01409170710751926

Ellingson, J. E., Gruys, M. L., \& Sackett, P. R. (1998). Factors related to the satisfaction and performance of temporary employees. J Appl Psychol. 83(6), 913. https://doi. org/10.1037/0021-9010.83.6.913

Engle, E. M., \& Lord, R. G. (1997). Implicit theories, selfschemas, and leader-member exchange. Acad Manage J . l, 40(4), 988-1010. https://doi.org/10.5465/256956

Gardner, W. L., Avolio, B. J., Luthans, F., May, D. R., \& Walumbwa, F. (2015). Can You See the Real Me? A Self-based Model ofAuthentic Leader and Follower Development. Leadership Quarterly, 16(3), 343-372. https://doi.org/10.1016/j. leaqua.2005.03.003

Goldberg, L. R. (1990). An alternative" description of personality": the big-five factor structure. J Pers Soc Psychol. 59(6), 1216. https://doi.org/10.1037/0022-3514.59.6.1216

Göbel, M., Vogel, R., \& Weber, C. (2013). Management research on reciprocity: A review of the literature. Business Research, 6(1), 34-53. https://doi.org/10.1007/BF03342741

Goldman, B. M. (2012). Making diamonds out of coal: therole of authenticity in healthy (optimal) self-esteem andpsychological functioning. In Self-Esteem Issues and Answers: A sourcebook of current perspectives. pp. 133-139. New York: Psychology Press.

Grubbs-West, L. (2015). Lessons in Loyalty: How Southwest Airlines Does It - An Insider's View (2nd, Ed.). Cornerstone Leadership Institute. 
Guest, D. (2004). Flexible employment contracts, the psychological contract and employee outcomes: an analysis and review of the evidence. Int. J. Manag. Rev. 5(1), 1-19. https://doi.org/10.1111/j.1460-8545.2004.00094.x

Guest, D. E., \& Conway, N. (2002). Communicating the psychological contract: an employer perspective. Hum. Resour. Manag. J., 12(2), 22-38. https://doi. org/10.1111/j.1748-8583.2002.tb00062.x

Guest, D., \& Conway, N. (2009). Health and well-being: The role of the psychological contract. International handbook of work and health psychology, 9-24. https://doi. org/10.1002/9780470682357.ch2

Gupta, P. D., Bhattacharya, S., Sheorey, P., \& Coelho, P. (2018). Relationship between onboarding experience and turnover intention: intervening role of locus of control and selfefficacy. Industrial and Commercial Training. https://doi. org/10.1108/ICT-03-2017-0023

Güth, W. (1995). On ultimatum bargaining experiments-A personal review. J Econ Behav Organ ., 27(3), 329-344. https://doi.org/10.1016/0167-2681(94)00071-L

Hirshleifer, D. (1988). Cooperation in a finitely repeated prisoner's dilemma game with ostracism. Los Angeles.

Haas, M. R., Criscuolo, P., \& George, G. (2015). Which problems to solve? Online knowledge sharing and attention allocation in organizations. Acad Manage J., 58(3), 680711. https://doi.org/10.5465/amj.2013.0263

Hesse, A. (January 2018). Digitalization and Leadership-How experienced leaders interpret daily realities in a digital world. In Proceedings of the $51^{\text {st }}$ Hawaii International Conference on System Sciences. https://doi.org/10.24251/ HICSS.2018.234

Horney, N. (2016). The gig economy: A disruptor requiring HR agility. People and Strategy,

Ilies, R., Morgeson, F. P., \& Nahrgang, J. D. (2005). Authentic leadership and eudaemonic well-being: Understanding leader-follower outcomes. The leadership quarterly, 16(3), 373-394. https://doi.org/10.1016/j.leaqua.2005.03.002

Jago, A. G. (1982). Leadership: Perspectives in theory and research. Management science, 28(3), 315-336. https://doi. org/10.1287/mnsc.28.3.315

J, A. B., \& Gardner, W. L. (2015). Authentic leadership development: Getting to the root of positive forms of leadership. The Leadership Quarterly, 16, 315-338. https://doi. org/10.1016/j.leaqua.2005.03.001
Kernis, M. H. (2003). Toward a conceptualization of optimal self-esteem. Psychological inquiry, 14(1), 1-26. https://doi. org/10.1207/S15327965PLI1401_01

Krausz, M., Bizman, A., \& Braslavsky, D. (2001). Effects of attachment style on preferences for and satisfaction with different employment contracts: An exploratory study. Journal of Business and Psychology, 16(2), 299-316. https:// doi.org/10.1023/A:1011169419048

Kreps, D. M., Milgrom, P., Roberts, J., \& Wilson, R. (1982). Rational cooperation in the finitely repeated prisoners' dilemma. J. Econ. Theory, 27(2), 245-252. https://doi. org/10.1016/0022-0531(82)90029-1

Klenke, K. (2016). Authentic Leadership: A Self,Leader, and Spiritual Identity perspective. Internationa Journal of Leadership Studies, 3(1), 68-97.

Lemmon, G., Westring, A., Michel, E. J., Wilson, M. S., \& Glibkowski, B. C. (2016). A cross-domain exploration of performance benefits and costs of idiosyncratic deals. J. Leadersh. Organ. Stud. 23(4), 440-455. https://doi. org/10.1177/1548051816645748

Levinson, H., Price, C. R., Munden, K. J., Mandl, H. J., \& Solley, C. M. (2013). Men, management, and mental health. Harvard University Press.

Marler, J. H., Woodard Barringer, M., \& Milkovich, G. T. (2002). Boundaryless and traditional contingent employees: Worlds apart. Journal of Organizational Behavior: The International Journal of Industrial, Occupational and Organizational Psychology and Behavior, 23(4), 425. https://doi.org/10.1002/job.148

McLean Parks, J., Kidder, D. L., \& Gallagher, D. G. (1998). Fitting square pegs into round holes: Mapping the domain of contingent work arrangements onto the psychological contract. Journal of Organizational Behavior: The International Journal of Industrial, Occupational and Organizational Psychology and Behavior, 19(S1), 697-730. https://doi. org/10.1002/(SICI)1099-1379(1998)19:1+<697::AIDJOB974>3.0.CO;2-I

Moritz, B. The PwC Diversity Journey: Creating Impact, Achieving Results/B. Moritz, A. Hussherr., 2016.-66 c.(PwC).

Neider, L. L., \& Schriesheim, C. A. (2011). The authentic leadership inventory (ALI): Development and empirical tests. The leadership quarterly, 22(6), 1146-1164. https://doi. org/10.1016/j.leaqua.2011.09.008

Nikolaou, I., Tomprou, M., \& Vakola, M. (2007). Individuals' inducements and the role of personality: implications for 
psychological contracts. J. Manag. Psychol. https://doi. org/10.1108/02683940710820082

Novicevic, M., Harvey, M., Buckley, M. G., Brown, M. R., \& Evans, R. (2006). Authentic leadership: A historical perspective. J. Leadersh. Organ. Stud., 13(1), 64-76. https:// doi.org/10.1177/10717919070130010901

Oliver E Willamson. (1993). Journal of Law and Economics, Vol XXXVI.

Pandey, S. N. (1989). Human side of Tata steel. Tata McGrawHill Publishing Company.

Porter, L. W., Pearce, J. L., Tripoli, A. M., \& Lewis, K. M. (1998). Differential perceptions of employers' inducements: Implications for psychological contracts. Journal of Organizational Behavior: The International Journal of Industrial, Occupational and Organizational Psychology and Behavior, 19(S1), 769-782. https://doi. org/10.1002/(SICI)1099-1379(1998)19:1+<769::AID JOB968>3.0.CO;2-1

PwC. (2016). The PwC diversity journey Creating impact, achieving results.

Raja, U., Johns, G., \& Ntalianis, F. (2004). The impact of personality on psychological contracts. Acad Manage J . 47(3), 350-367. https://doi.org/10.5465/20159586

Rego, A., Júnior, D. R., \& e Cunha, M. P. (2015). Authentic leaders promoting store performance: The mediating roles of virtuousness and potency. "J. Bus. Ethics 128(3), 617-634. https://doi.org/10.1007/s10551-014-2125-8

Richter, A., \& Wagner, D. (January 2014). Leadership 2.0: Engaging and supporting leaders in the transition towards a networked organization. In $201447^{\text {th }}$ Hawaii International Conference on System Sciences (pp. 574-583). IEEE. https://doi.org/10.1109/HICSS.2014.78

Robinson, S. L., \& Wolfe Morrison, E. (2000). The development of psychological contract breach and violation: A longitudinal study. JJ. Organ. Behav. 21(5), 525-546. https:// doi.org/10.1002/1099-1379(200008)21:5<525::AID JOB40>3.0.CO;2-T

Rousseau, D. (1995). Psychological contracts in organizations: Understanding written and unwritten agreements. Sage publications. https://doi.org/10.4135/9781452231594

Rousseau, D. M. (2004). Psychological contracts in the workplace: Understanding the ties that motivate. Academy of Management Perspectives, 18(1), 120-127. https://doi. org/10.5465/ame.2004.12689213

Rousseau, D. M. (2001). Schema, promise and mutuality: The building blocks of the psychological contract.
J. Occup. Organ. Psychol., 74(4), 511-541. https://doi. org/10.1348/096317901167505

Rousseau, D. M., \& Tijoriwala, S. (April 1996). Perceived legitimacy and unilateral contract changes: It takes a good reason to change a psychological contract. In Symposium at the SIOP meetings, San Diago.

Rousseau, D. M., \& Tijoriwala, S. A. (1998). Assessing psychological contracts: Issues, alternatives and measures. Journal of Organizational Behavior: The International Journal of Industrial, Occupational and Organizational Psychology and Behavior, 19(S1), 679-695. https://doi. org/10.1002/(SICI)1099-1379(1998)19:1+<679:AIDJOB971>3.0.CO;2-N

Sendjaya, S., Pekerti, A., Härtel, C., Hirst, G., \& Butarbutar, I. (2016). Are authentic leaders always moral? The role of Machiavellianism in the relationship between authentic leadership and morality. J. Bus. Ethics, 133(1), 125-139. https://doi.org/10.1007/s10551-014-2351-0

Shah, S. (2010). Employee and labour welfare at the Tata Group Companies. Management and Labour Studies, 35(3), 311336. https://doi.org/10.1177/0258042X1003500301

Shah, S. (2014). Corporate social responsibility: A way of life at the Tata Group. J. Hum. Values, 20(1), 59-74. https://doi. org/10.1177/0971685813515591

Sharma, M. K., \& Jain, S. (2013). Leadership management: Principles, models and theories. Global Journal of Management and Business Studies, 3(3), 309-318.

Sherman, U. P., \& Morley, M. J. (2015). On the formation of the psychological contract: A schema theory perspective. Group \& Organization Management, 40(2), 160-192. https://doi.org/10.1177/1059601115574944

Sinha, J. B. P., \& Mohanty, S. K. (2006). Tata Steel: becoming world class. Shri Ram Centre.

Smidts, A., Pruyn, A. T. H., \& Van Riel, C. B. (2001). The impact of employee communication and perceived external prestige on organizational identification. Acad Manage J. 44(5), 1051-1062. https://doi.org/10.5465/3069448

Smith, A. (1937). The wealth of nations [1776] (Vol. 11937).

Sharma, M., \& Jain, S. (2013). Leadership management: Principles, Models and Theories. Global Journal of Management and Business Studies, 3(3).

Sherman, U. P., \& Morley, M. J. (2015). On the Formation of the Psychological Contract: A Schema Theory Perspective. Group \& Organization Management, 40(2), 160-192. https://doi.org/10.1177/1059601115574944 
Terry, R. (1993). Authentic leadership. San Francisco: JosseyBass.

Tallman, R. R., \& Bruning, N. S. (2008). Relating employees' psychological contracts to their personality. J. Manag. Psychol. https://doi.org/10.1108/02683940810894756

Taylor, M. S., \& Tekleab, A. G. (2004). Taking stock of psychological contract research: Assessing progress, addressing troublesome issues, and setting research priorities. The employment relationship: Examining psychological and contextual perspectives, 253-283.

Terry, R. W. (1993). Authentic leadership: Courage in action (No. 658.409 T2791a Ej. 1 000012). JOSSEY-BASS.

Tremlett, N., \& Collins, D. (1999). Temporary Employment in Great Britain. Norwich: Department for Education and Employment.

Tripathi, R., \& Kumar, A. (2020). Humanistic leadership in the Tata group: the synergy in personal values, organisational strategy and national cultural ethos. Cross Cultural \& Strategic Management. https://doi.org/10.1108/CCSM-012020-0025

Tufan, P., De Witte, K., \& Wendt, H. J. (2019). Diversity-related psychological contract breach and employee work behavior: insights from intergroup emotions theory. The Int. J.
Hum. Resour. Manag. 30(20), 2925-2949. https://doi.org/1 $0.1080 / 09585192.2017 .1350733$

Walumbwa, F. O., Avolio, B. J., Gardner, W. L., Wernsing, T. S., \& Peterson, S. J. (2008). Authentic leadership: Development and validation of a theory-based measure. J. Manag. Stud., 34(1), 89-126. https://doi.org/10.1177/0149206307308913

Wellin, M. (2016). Managing the psychological contract: Using the personal deal to increase business performance. CRC Press. https://doi.org/10.4324/9781315593661

Yuki, G. A. (2010). Leadership in Organizations edition $7^{\text {th }}$.

Zhao, D., Zuo, M., \& Deng, X. N. (2015). Examining the factors influencing cross-project knowledge transfer: An empirical study of IT services firms in China. Int. J. Proj. Manag., 33(2), 325-340. https://doi.org/10.1016/j.ijproman.2014.05.003

Yarbrough, J. R. (2009). Understanding the importance of the employee/employer psychological contract. Journal of Management and Marketing Research, 21, 9.

Yuki, G. (2010). Leadership in organizations ( $7^{\text {th }}$ ed.). Upper Saddle River, NJ: Prentice Hall. 